\title{
Pyrolysis Characteristics and Kinetic Analysis of Sediment from the Dianchi Lake in China
}

\author{
Zhenfen $W u(\mathbb{D})^{1,2}$ and Huilong Luo $\mathbb{D}^{1}$ \\ ${ }^{1}$ Faculty of Architecture Engineering, Kunming University of Science and Technology, Kunming 650224, China \\ ${ }^{2}$ Faculty of Modern Agricultural Engineering, Kunming University of Science and Technology, Kunming 650224, China
}

Correspondence should be addressed to Huilong Luo; km_lhl@163.com

Received 12 October 2017; Revised 26 December 2017; Accepted 9 January 2018; Published 8 February 2018

Academic Editor: Badie I. Morsi

Copyright (C) 2018 Zhenfen Wu and Huilong Luo. This is an open access article distributed under the Creative Commons Attribution License, which permits unrestricted use, distribution, and reproduction in any medium, provided the original work is properly cited.

\begin{abstract}
Pyrolysis properties and kinetic analysis of lake sediment, as well as evolution characteristics of the gaseous products at $5^{\circ} \mathrm{C} / \mathrm{min}$, $10^{\circ} \mathrm{C} / \mathrm{min}$, and $20^{\circ} \mathrm{C} / \mathrm{min}$, were investigated by TG-FTIR. Comparison to the TG and DTG curves at different heating rates, the pyrolysis process at $10^{\circ} \mathrm{C} / \mathrm{min}$ could describe the sediment pyrolysis characteristics better than at $5^{\circ} \mathrm{C} / \mathrm{min}$ and $20^{\circ} \mathrm{C} / \mathrm{min}$; thus the process of sediment pyrolysis could be considered as four stages. From the kinetics analysis, the nth-order chemical reaction model was suitable to describe the sediment pyrolysis reaction well. The values of $\mathrm{n}$ were within 2.55-3.42 and activation energy $E$ was ranged from $15.83 \mathrm{KJ} / \mathrm{mol}$ to $57.92 \mathrm{KJ} / \mathrm{mol}$ at different heating rates. The gaseous products of $\mathrm{H}_{2} \mathrm{O}, \mathrm{CO}_{2}, \mathrm{CO} \mathrm{CH}_{4}$, and $\mathrm{SO}_{2}$ and several functional groups $(\mathrm{C}-\mathrm{H}, \mathrm{C}=\mathrm{O}$, and $\mathrm{C}-\mathrm{O})$ could be found from the IR spectrum. From the evolution characteristics with the temperature, there were two evolution peaks for $\mathrm{CO}_{2}$ and one peak for $\mathrm{CH}_{4}$ and $\mathrm{SO}_{2}$. However, the evolution of $\mathrm{CO}$ always increased. Besides, the evolution peak for $\mathrm{CO}_{2}, \mathrm{CH}_{4}$, and $\mathrm{SO}_{2}$ all shifted to the low temperature region with the decrease of heating rate. The results could provide theoretical basis for harmless treatment and resource utilization of lake sediment.
\end{abstract}

\section{Introduction}

Lake sediment is the migration and transformation carrier of a large number of organic pollutants in the environment, which can be regarded as the second pollution source of water [1]. In order to improve the water quality of lake, sediment dredging is considered as an important mean of water pollution control [2]. The first large-scale lake dredging project in China was Dianchi sediment dredging project in 1998; so far, the lake sediment has been dredged about 14.94 million $\mathrm{m}^{3}$ [3]. The treatment methods of the dredged sediment are bowing and filling cofferdam and landfill after mechanical dewatering [4]; however, these methods could lead to serious environmental destruction and groundwater pollution. Thus, how to scientifically deal with the large quantity of sediment with complex composition and achieve its reduction, stabilization, harmless, and resource has become one of the problems that the domestic and international environmental protection organizations are concerned with.

At present, the most common sediment treatment methods are landfill, preparation of fertilizer, preparation of building material, and pyrolysis [5]. However, considering the farm limitations and heavy metal harm, the landfill and preparation of fertilizer as well as building material are becoming more and more difficult to operate $[6,7]$. Thus, pyrolysis was identified to be a promising sediment treatment technology, because it is a zero-waste method that can convert sediment into useful bioenergy. Pyrolysis is the thermal decomposition of raw materials at elevated temperatures in an inert atmosphere, and the main products are vapors including condensable and noncondensable gases, liquid bio-oils, and solid char [8].

Several reports studied some pyrolysis characteristics of lake sediment. Zhang et al. [9] studied the copyrolysis behaviors of coal slime and river sediment using the method of liner warming. They indicated that the river sediment played a catalytic role on coal slime pyrolysis. Gu et al. [10] studied the variation of heavy metal speciation during pyrolysis of sediment from the Dianchi Lake in China. They indicated that the heavy metals $\mathrm{Cd}, \mathrm{Cu}, \mathrm{Zn}$, and $\mathrm{Pb}$ speciated in thermally treated sediments showed different patterns from that of the lake sediment and pyrolysis temperature 
had a great impact on the fractional distribution of heavy metals. Wang et al. [11] studied cogasification of Dianchi sediment and lignite for hydrogen production in supercritical water. They indicated that the cogasification of sediment and lignite is a process with a high recovery of gaseous products but low gasification yields. However, few studies focused on the kinetic analysis of pyrolysis for lake sediment. In order to obtain a better understanding of the chemical and physical characteristics of sediment pyrolysis as well as reasonable devolatilization mechanism, it is necessary to do many contributions to the kinetic study of lake sediment pyrolysis. Some studies about pyrolysis characteristics of sediment from the Dianchi Lake have been done in the early stage [4].

Thermogravimetric (TG) analysis is one of the most common thermal analysis techniques [12], but it can only give thermal decomposition temperature and thermal gravimetric percent content and not give qualitative results of volatile gases. However, TG-FTIR technology makes up the shortcomings of thermogravimetric method. Several researchers had studied the characteristics of various fuels pyrolysis through TG-FTIR, and some reaction models have been built to predict the biomass pyrolysis mechanism [13-15]. Through the TG-FTIR analysis, not only can the kinetic parameters be obtained by TG, but also the gas releasing from pyrolysis can be received, which can provide deeper understanding of the mechanism of pyrolysis, so it is widely used in thermal stability and thermal decomposition mechanism of a variety of organic and inorganic materials.

The purpose of this work was to investigate the thermal degradation characteristics and pyrolysis kinetics of Dianchi Lake sediment through TG analysis at different heating rates. Meanwhile, FTIR coupled with TG was used to characterize the several main gaseous products evolved.

\section{Materials and Methodology}

2.1. Materials. The raw sediment was collected from the Caihai region of the Dianchi Lake in Kunming, China, and the water content was $68.25 \%$. The sediment was subjected to drying ( $378 \mathrm{~K}$ for $24 \mathrm{~h}$ ) and crushing and screening (through a $2 \mathrm{~mm}$ sieve). The ultimate analyses of the raw sediment are shown in Table 1, and Table 2 shows proximate analysis of the raw sediment.

2.2. TG-FTIR Analysis. The thermal pyrolysis of the raw sediment was carried out online by a TGA type (NETZSCH, STA 449F3, Germany) coupled with a FTIR type (BRUKER, ALPHA, Germany). After pass $\mathrm{N} 2$ for $5 \mathrm{~min}$ at $30 \mathrm{~mL} / \mathrm{min}$, about 3.7-4.2 mg samples were inserted into the TGA apparatus. When the samples were started to be heated from $40^{\circ} \mathrm{C}$ to $1000^{\circ} \mathrm{C}$ at three different heating rates $\left(5^{\circ} \mathrm{C} / \mathrm{min}, 10^{\circ} \mathrm{C} / \mathrm{min}\right.$, and $20^{\circ} \mathrm{C} / \mathrm{min}$ ), the volatiles released were collected and analyzed by the FTIR with spectrum ranging from $4000 \mathrm{~cm}^{-1}$ to $400 \mathrm{~cm}^{-1}$ and a resolution of $1 \mathrm{~cm}^{-1}$. In order to reduce the test error to less than $5 \%$, all the tests were repeated three times.
TABLE 1: Ultimate analysis of the raw sediment.

\begin{tabular}{|c|c|c|}
\hline Order number & Element & Content (wt $\%)$ \\
\hline (1) & $\mathrm{O}$ & 28.1508 \\
\hline (2) & $\mathrm{C}$ & 22.2431 \\
\hline (3) & $\mathrm{Si}$ & 12.5684 \\
\hline (4) & $\mathrm{Al}$ & 11.4125 \\
\hline (5) & $\mathrm{Fe}$ & 8.3655 \\
\hline (6) & $\mathrm{Ca}$ & 6.5481 \\
\hline (7) & $\mathrm{H}$ & 2.9828 \\
\hline (8) & $\mathrm{N}$ & 1.5641 \\
\hline (9) & S & 1.4836 \\
\hline (10) & K & 0.9562 \\
\hline (11) & $\mathrm{Mg}$ & 0.7521 \\
\hline (12) & $\mathrm{Ti}$ & 0.6213 \\
\hline (13) & $\mathrm{P}$ & 0.4089 \\
\hline (14) & $\mathrm{V}$ & 0.3352 \\
\hline (15) & $\mathrm{Na}$ & 0.3056 \\
\hline (16) & $\mathrm{Cu}$ & 0.2944 \\
\hline (17) & $\mathrm{Ba}$ & 0.2256 \\
\hline (18) & $\mathrm{Zn}$ & 0.2093 \\
\hline (19) & $\mathrm{Mn}$ & 0.1955 \\
\hline (20) & $\mathrm{Zr}$ & 0.1923 \\
\hline$(21)$ & $\mathrm{Ni}$ & 0.1365 \\
\hline (22) & $\mathrm{Cr}$ & 0.0125 \\
\hline (23) & $\mathrm{Sr}$ & 0.0095 \\
\hline (24) & $\mathrm{Y}$ & 0.0066 \\
\hline (25) & $\mathrm{Rb}$ & 0.0058 \\
\hline (26) & $\mathrm{Cl}$ & 0.0057 \\
\hline (27) & Mo & 0.0043 \\
\hline (28) & $\mathrm{Ga}$ & 0.0021 \\
\hline (29) & $\mathrm{Pb}$ & 0.0015 \\
\hline (30) & As & 0.0002 \\
\hline
\end{tabular}

TABLE 2: Proximate analysis of the raw sediment.

\begin{tabular}{lcccc}
\hline \multirow{2}{*}{ Material } & \multicolumn{4}{c}{ Proximate analysis (wt.\%) } \\
& $M$ & $V$ & FC & $A$ \\
\hline Sediment & 8.44 & 40.46 & 7.67 & 43.43 \\
\hline
\end{tabular}

2.3. Pyrolysis Kinetic Analysis. According to Arrhenius equation, the pyrolysis reaction kinetics for lake sediment can be described as [16-18]

$$
\frac{d \alpha}{d t}=k(T) f(\alpha)=A \exp \left(-\frac{E}{R T}\right) f(\alpha)
$$

where $\alpha$ is the reaction conversion degree, $t$ is the time (min), $T$ is the temperature $(\mathrm{K}), f(\alpha)$ is the mechanism function equation, $A$ is the preexponential factor $\left(\mathrm{s}^{-1}\right), E$ is the activation energy $(\mathrm{KJ} / \mathrm{mol})$, and $R$ is the universal gas constant $(\mathrm{J} /(\mathrm{mol} \cdot \mathrm{K})) . \alpha$ is obtained by the following equation:

$$
\alpha=\frac{w_{i}-w}{w_{i}-w_{f}}
$$


TABLE 3: Characteristic parameters for sediment pyrolysis at different heating rates.

\begin{tabular}{|c|c|c|c|c|c|c|c|c|c|}
\hline $\begin{array}{l}\text { Heating rate } \\
\left({ }^{\circ} \mathrm{C} / \mathrm{min}\right)\end{array}$ & $\begin{array}{l}T_{1}^{a} \\
\left({ }^{\circ} \mathrm{C}\right)\end{array}$ & $\begin{array}{l}T_{2}{ }^{\mathrm{a}} \\
\left({ }^{\circ} \mathrm{C}\right)\end{array}$ & $\begin{array}{l}T_{3}{ }^{\mathrm{a}} \\
\left({ }^{\circ} \mathrm{C}\right) \\
\end{array}$ & $\begin{array}{l}T_{4}{ }^{\mathrm{a}} \\
\left({ }^{\circ} \mathrm{C}\right)\end{array}$ & $\begin{array}{c}\mathrm{DTG}_{\max 1}{ }^{\mathrm{b}} \\
(\% / \mathrm{min})\end{array}$ & $\begin{array}{l}\mathrm{DTG}_{\max 2}{ }^{\mathrm{b}} \\
(\% / \mathrm{min})\end{array}$ & $\begin{array}{c}\mathrm{DTG}_{\max 3}{ }^{\mathrm{b}} \\
(\% / \mathrm{min})\end{array}$ & $\begin{array}{l}\mathrm{DTG}_{\max 4}{ }^{\mathrm{b}} \\
(\% / \mathrm{min})\end{array}$ & $\begin{array}{l}M_{f}^{c} \\
(\%)\end{array}$ \\
\hline 20 & 112.25 & 359.85 & 728.73 & 1 & -2.30 & -2.67 & -2.54 & 1 & 49.56 \\
\hline 10 & 100.78 & 290.14 & 650.38 & 920.67 & -2.41 & -2.66 & -2.55 & -1.25 & 47.71 \\
\hline 5 & 100.01 & 263.88 & 637.14 & 901.56 & -2.52 & -2.66 & -2.56 & -1.28 & 47.44 \\
\hline
\end{tabular}

${ }^{\mathrm{a}} T_{1}, T_{2}, T_{3}$, and $T_{4}$ : the temperature according to the first, the second, the third, and the fourth weight loss peak, respectively; ${ }^{\mathrm{b}} \mathrm{DTG} \mathrm{G}_{\max 1}, \mathrm{DTG}_{\max 2}, \mathrm{DTG} \mathrm{m}_{\mathrm{max} 3}$, and $\mathrm{DTG}_{\max 4}$ : the maximum mass loss rate according to the first, the second, the third, and the fourth peak, respectively; ${ }^{\mathrm{c}} M_{f}$ : the residual mass fraction.

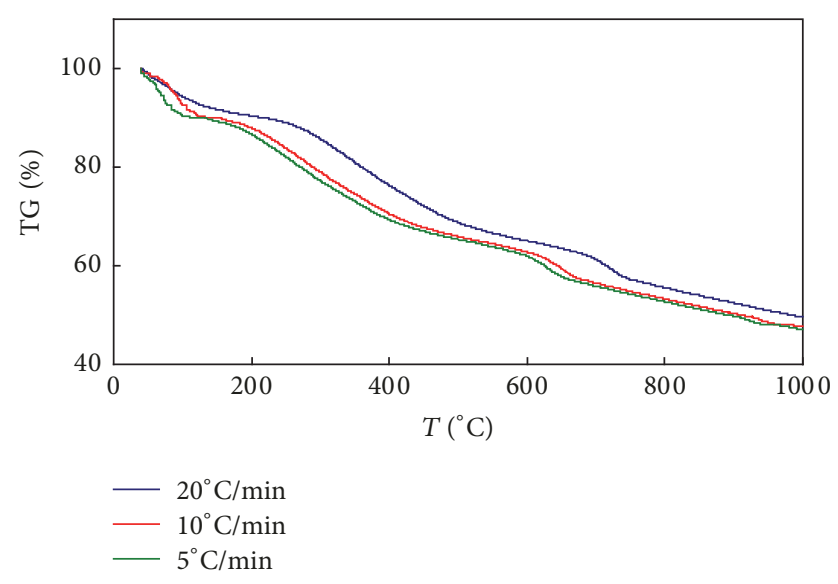

FIGURE 1: The TG curves for pyrolysis of sediment at different heating rates.

where $w$ is the mass of sample at time $t(\mathrm{mg})$ and $w_{i}$ and $w_{f}$ are the initial mass and final mass of sample, respectively (mg). Equation (1) could be transformed by integration to

$$
\ln \left(\frac{g(\alpha)}{T^{2}}\right)=-\frac{E}{R} \cdot \frac{1}{T}+\ln \left(\frac{A R}{\beta E}\right),
$$

where $\beta$ is a constant heating rate $\left({ }^{\circ} \mathrm{C} / \mathrm{min}\right)$ and $g(\alpha)$ is a $n$ thorder chemical reaction and could be described as

$$
g(\alpha)=\frac{\left[(1-\alpha)^{-(n-1)}-1\right]}{(n-1)} .
$$

An appropriate $n$ was chosen; a straight line could be drawn by plotting $\ln \left(g(\alpha) / T^{2}\right)$ versus $1 / T$. Thus, the kinetic parameters $E$ and preexponential factor $A$ can be determined by the slope and intercept of the linear line, respectively.

\section{Results and Discussion}

\subsection{TGA Analysis and Kinetic Parameter from Pyrolysis of Sediment}

3.1.1. TG and DTG Analysis. The TG and DTG curves of sediment pyrolysis at different heating rates were illustrated in Figures 1 and 2, respectively. As shown in Figure 1, the remaining mass fraction curve was shifted down the temperature scale by a decrease in the heating rate. From Figure 2, it is seen that there were three weight loss peaks at $20^{\circ} \mathrm{C} / \mathrm{min}$, but there were four weight loss peaks at $5^{\circ} \mathrm{C} / \mathrm{min}$ and $10^{\circ} \mathrm{C} / \mathrm{min}$.

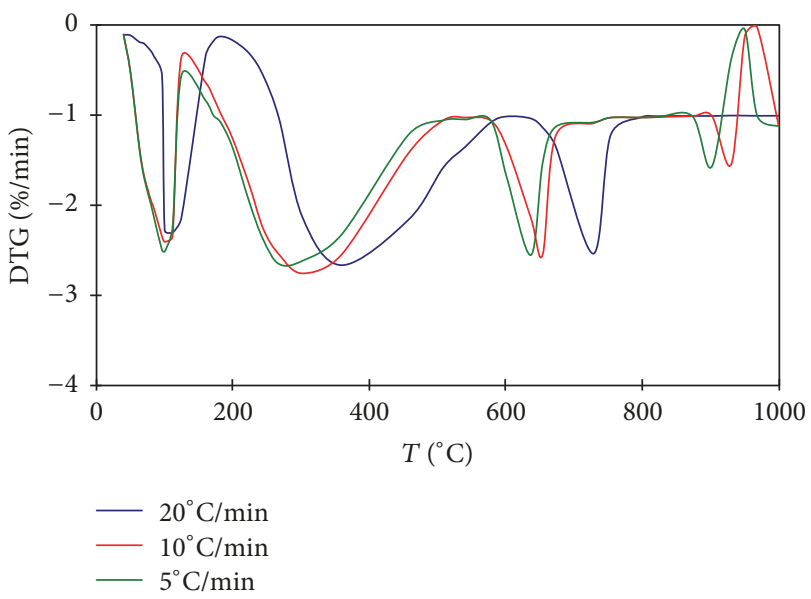

FIGURE 2: The DTG curves for pyrolysis of sediment at different heating rates.

The devolatilization process of sediment samples occurred in a range of temperature between $200^{\circ} \mathrm{C}$ and $800^{\circ} \mathrm{C}$. The characteristic parameters for sediment sample pyrolysis at different heating rates were presented in Table 3; it is known that the temperatures according to the first, the second, the third, and the fourth weight loss peaks at $10^{\circ} \mathrm{C} / \mathrm{min}$ were lower than that at $20^{\circ} \mathrm{C} / \mathrm{min}$, respectively. It is indicated that the occurrence of weight loss peaks tended to low temperature region with the decrease of heating rate. Meanwhile, the maximum mass loss rates according to the first, the second, the third, and the fourth peaks were slightly higher than that at $20^{\circ} \mathrm{C} / \mathrm{min}$, respectively. It is indicated that the reaction was more intense with the decrease of heating rate. Meanwhile, the lack of the fourth peak and the higher $M_{f}$ value at $20^{\circ} \mathrm{C} / \mathrm{min}$ indicated that the pyrolysis reaction of sediment might be incomplete at high heating rate. The phenomenon was attributed to the fact that the short reaction time at high heating rate would interfere with the release of volatiles in pyrolysis. Although there is little difference in TG and DTG curves between $5^{\circ} \mathrm{C} / \mathrm{min}$ and $10^{\circ} \mathrm{C} / \mathrm{min}$, reaction time was shorter and efficiency was higher at $10^{\circ} \mathrm{C} / \mathrm{min}$ than those at $5^{\circ} \mathrm{C} / \mathrm{min}$. To conclude, the pyrolysis process at $10^{\circ} \mathrm{C} / \mathrm{min}$ could describe the sediment pyrolysis characteristics better than at $5^{\circ} \mathrm{C} / \mathrm{min}$ and $20^{\circ} \mathrm{C} / \mathrm{min}$.

During the whole sediment pyrolysis process at the heating rate of $10^{\circ} \mathrm{C} / \mathrm{min}$, four stages were considered: (a) in the first stage while the temperature was from $40^{\circ} \mathrm{C}$ to $160^{\circ} \mathrm{C}$, the total weight loss was accounting for about $12.15 \%$ 
of total weight of sample, which was attributed to the release of $8.44 \%$ moisture (shown in Table 1) and crystal water, as well as the decomposition of a certain amount of smallmolecule reactive components. (b) The second stage ranged from $160^{\circ} \mathrm{C}$ to $520^{\circ} \mathrm{C}$, the total weight loss was accounting for about $23.36 \%$, and the volatile matter of a large number of light organic compounds such as alcohols and saccharides [19], as well as macromolecule organic matters such as proteins, cellulose, and semicellulose polysaccharides and saturated aliphatic chains, were mainly decomposed in this stage. The products of the stage were mainly carbon dioxide, combustible gas, tar, and coke. (c) The third stage was from $520^{\circ} \mathrm{C}$ to $780^{\circ} \mathrm{C}$, and the total weight loss was accounting for about $10.41 \%$, which was attributed to the decomposition of a small part of macromolecule organic matters and secondary cracking of tar and coke generated in the second stage. (d) The fourth stage was above $780^{\circ} \mathrm{C}$, and the total weight loss was accounting for about $6.25 \%$. As shown in Table 2 , this was mainly due to the following: the partly decomposition of mineral salts such as combinations of $\mathrm{SiO}_{2}$ and other oxides (mostly metal oxide) [20] and then $\mathrm{SiO}_{2}$ and $\mathrm{C}$ reacted to produce $\mathrm{SiC}$ and $\mathrm{CO}$ at high temperature. As for at the heating rate of $20^{\circ} \mathrm{C} / \mathrm{min}$, three stages were considered. The first stage extended from $40^{\circ} \mathrm{C}$ to $180^{\circ} \mathrm{C}$, and the total weight loss was accounting for about $10.55 \%$ of total weight of sample, which was attributed to the release of moisture and crystal water. The second stage was from $180^{\circ} \mathrm{C}$ to $600^{\circ} \mathrm{C}$, and the total weight loss was accounting for about $27.54 \%$, which was due to the decomposition of a large number of light organic compounds and macromolecule organic matters. The third stage was above $600^{\circ} \mathrm{C}$, and the total weight loss was accounting for about $12.27 \%$, which was due to partly secondary cracking of tar and coke generated in the second stage and decomposition of inorganic matters.

3.1.2. Kinetic Analysis. From the above description, the organics thermal degradation mainly occurred in the second and third stages in DTG analysis; thus the two stages were regarded as the main reaction region during sediment pyrolysis. The two temperature regions from $160^{\circ} \mathrm{C}$ to $520^{\circ} \mathrm{C}$ and from $520^{\circ} \mathrm{C}$ to $780^{\circ} \mathrm{C}$ at different heating rates were chosen for kinetic comparison analysis, which were marked as the first and the second organics degradation stage, respectively.

The fitting of $\ln \left(g(\alpha) / T^{2}\right)$ versus $1 / T$ lines for the first and the second organics degradation stage at different heating rates was established and presented in Figure 3, where numbers 1 and 2 inside parentheses indicated the order of stages. From Figure 3, it is known that all the correlation coefficients $R^{2}$ of fitting lines were above 0.992 , which indicated that the $n$ th-order chemical reaction model was suitable to describe the lake sediment pyrolysis reaction well.

The best $n$ values, activation energies, and preexponential factors of kinetic analysis at organics degradation stage were presented in Table 4 . The values of $n$ at different heating rates were between 2.55 and 3.42. The value of reaction order $n$ greater than 1 can be justified to correspond to the case of composite compounds [21]. The reaction order $n$, activation energy $E$, and preexponential factor $A$ of the

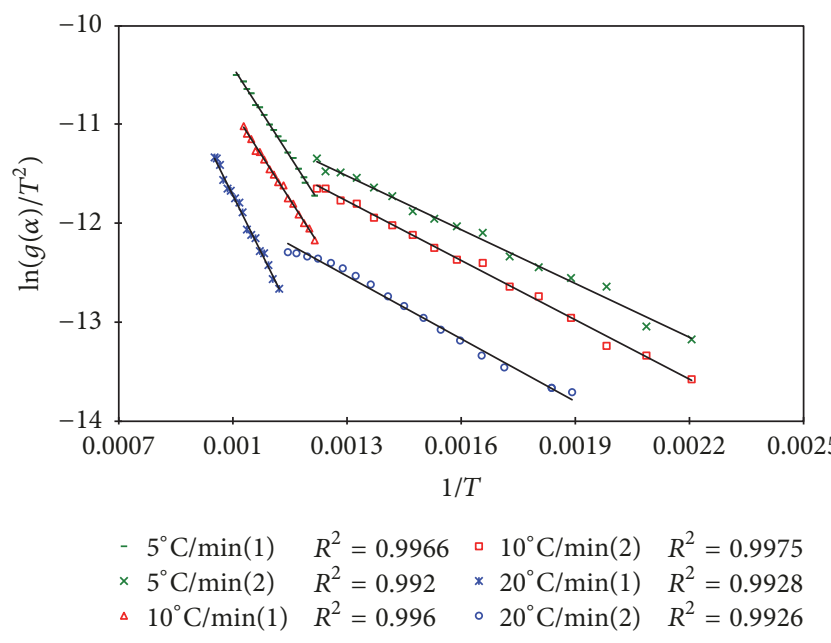

FIgURE 3: Kinetic fitting lines of organics degradation stages at different heating rates.

second organic degradation stage were greater than those of the first stage at any heating rate, which was due to the complexity of macromolecule organic matters degradation at second stage. Meanwhile, all kinetic parameters at heating rate of $20^{\circ} \mathrm{C} / \mathrm{min}$ were higher than at $10^{\circ} \mathrm{C} / \mathrm{min}$, which showed that the sediment pyrolysis reaction at $10^{\circ} \mathrm{C} / \mathrm{min}$ was easier than at $20^{\circ} \mathrm{C} / \mathrm{min}$. The decrease of heating rate made the temperature distribution of sediment particles more uniform, and the pyrolysis volatiles could be released in time to ensure the smooth progress of the internal thermal decomposition.

\subsection{TG-FTIR for the Gaseous Products during Sediment Pyrolysis}

3.2.1. Analysis of the FTIR Spectra. According to the four decomposition stages of sediment pyrolysis at heating rate of $10^{\circ} \mathrm{C} / \mathrm{min}$, the temperatures of $100^{\circ} \mathrm{C}, 290^{\circ} \mathrm{C}, 650^{\circ} \mathrm{C}$, and $920^{\circ} \mathrm{C}$ corresponding to the maximum decomposition rate of four stages according to DTG analysis were chosen as TGFTIR analysis objects, respectively. The gaseous products of $\mathrm{H}_{2} \mathrm{O}, \mathrm{CO}_{2}, \mathrm{CO}, \mathrm{CH}_{4}$, and $\mathrm{SO}_{2}$ and several functional groups ( $\mathrm{C}-\mathrm{H}, \mathrm{C}=\mathrm{O}$, and $\mathrm{C}-\mathrm{O}$ ) could be found from the IR spectrum in Figure 4. However, $\mathrm{H}_{2}$ as a common gas during biomass pyrolysis did not get detected by IR spectrum, which was due to weak infrared absorption of $\mathrm{H}_{2}$ [22]; thus $\mathrm{H}_{2}$ will be detected by gas chromatography in the future research.

As shown in Figure 5, the different IR spectra were complex with a great deal of absorption bands. However, five noticeable absorption bands could be distinguished, which were $4000-3500 \mathrm{~cm}^{-1}, 3250-2850 \mathrm{~cm}^{-1}, 2500-2100 \mathrm{~cm}^{-1}$, $1850-1250 \mathrm{~cm}^{-1}$, and $900-500 \mathrm{~cm}^{-1}$. The IR spectrum of sediment pyrolysis at $100^{\circ} \mathrm{C}$ had high absorbance that occurred in the region of $3800-3500 \mathrm{~cm}^{-1}$ and $1600-1350 \mathrm{~cm}^{-1}$ corresponding to $\mathrm{H}_{2} \mathrm{O}$, which was due to the release of moisture and crystal water. Meanwhile, there was obvious absorbance peak in the region of $2400-2240 \mathrm{~cm}^{-1}$ corresponding to $\mathrm{CO}_{2}$, which was attributed to decomposition of a certain amount of small-molecule reactive components. The IR spectrum 
TABLE 4: Kinetic parameters of organics degradation stages at different heating rates.

\begin{tabular}{|c|c|c|c|c|c|c|}
\hline \multirow{2}{*}{$\begin{array}{l}\text { Heating rate } \\
{ }^{\circ} \mathrm{C} / \mathrm{min}\end{array}$} & \multicolumn{3}{|c|}{ First organics degradation stage } & \multicolumn{3}{|c|}{ Second organics degradation stage } \\
\hline & $n$ & $E / \mathrm{KJ} \mathrm{mol}^{-1}$ & $A / \mathrm{s}^{-1}$ & $n$ & $E / \mathrm{KJ} \mathrm{mol}^{-1}$ & $A / \mathrm{s}^{-1}$ \\
\hline 20 & 2.97 & 18.02 & 1.88 & 3.42 & 57.92 & 661.61 \\
\hline 10 & 2.63 & 16.29 & 1.36 & 3.15 & 51.42 & 589.94 \\
\hline 5 & 2.55 & 15.83 & 1.31 & 3.03 & 50.67 & 574.18 \\
\hline
\end{tabular}

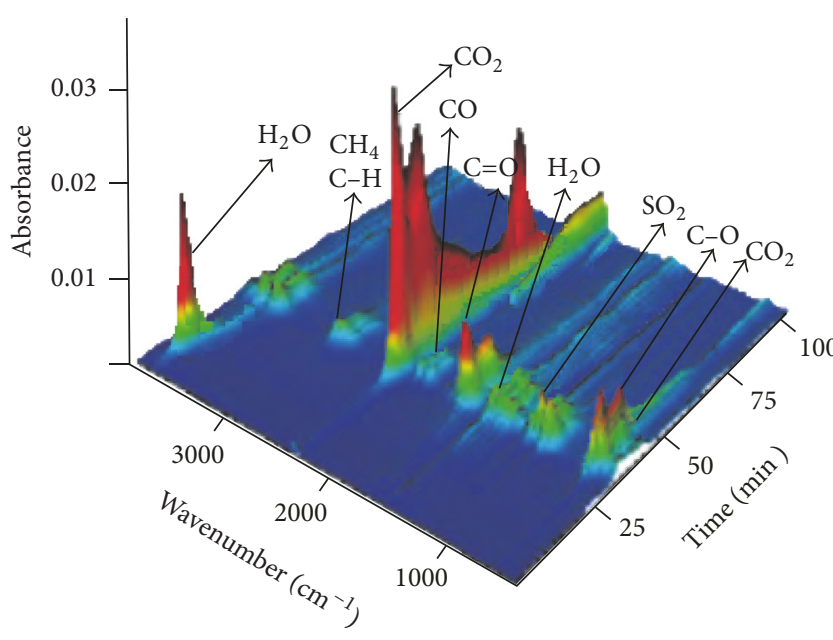

FIGURE 4: Three-dimensional FTIR of gaseous products obtained from sediment pyrolysis.

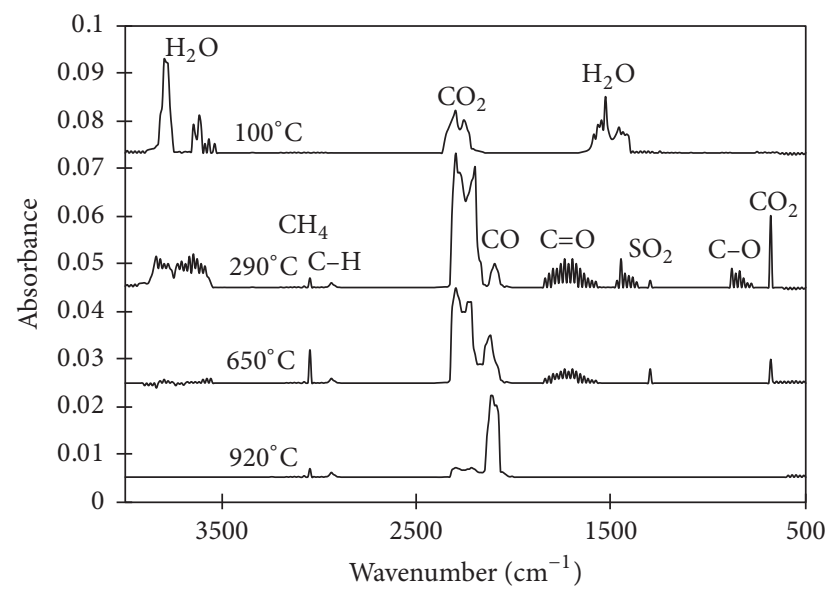

FIGURE 5: IR spectrum of gaseous products obtained from sediment pyrolysis at several selected temperatures.

of sediment pyrolysis at $290^{\circ} \mathrm{C}$ had high absorbance in the region of $2400-2240 \mathrm{~cm}^{-1}$ and $750-620 \mathrm{~cm}^{-1}$ corresponding to $\mathrm{CO}_{2}$. The absorbance intensity of $\mathrm{CO}_{2}$ in the IR spectrum at $290^{\circ} \mathrm{C}$ was higher than that at $100^{\circ} \mathrm{C}$, and the absorbance intensity of $\mathrm{H}_{2} \mathrm{O}$ at $290^{\circ} \mathrm{C}$ was lower than that at $100^{\circ} \mathrm{C}$. Besides, there were obvious absorbance peaks that occurred in the region of $3250-2850 \mathrm{~cm}^{-1}, 2250-2100 \mathrm{~cm}^{-1}$, and $1750-1400 \mathrm{~cm}^{-1}$ corresponding to $\mathrm{CH}_{4}, \mathrm{CO}$, and $\mathrm{SO}_{2}$, respectively, which was attributed to decomposition of proteins, cellulose, and semicellulose polysaccharides and saturated aliphatic chains. The generation of $\mathrm{C}-\mathrm{H}$ functional groups (present in hydrocarbons and methane), $\mathrm{C}=\mathrm{O}$ functional groups (present in esters, aldehydes, ketones, etc.), and C$\mathrm{O}$ functional groups (present in phenol, alcohols, ethers, etc.) [23] in the regions of $3200-2850 \mathrm{~cm}^{-1}, 1850-1600 \mathrm{~cm}^{-1}$, and $900-750 \mathrm{~cm}^{-1}$ corresponding to the lipids and proteins decomposition. The absorbance intensity of $\mathrm{CO}_{2}$ and $\mathrm{H}_{2} \mathrm{O}$ in the IR spectrum at $650^{\circ} \mathrm{C}$ were lower than that at $290^{\circ} \mathrm{C}$; however, the absorbance intensity of $\mathrm{CH}_{4}, \mathrm{CO}$, and $\mathrm{SO}_{2}$ at $650^{\circ} \mathrm{C}$ increased, which were due to secondary cracking of tar and coke generated in previous reaction and decomposition of the sulfur components in sediment. For $920^{\circ} \mathrm{C}$, it was clear that the intensity of IR spectrum was very weak, indicating that the decomposition of organics matters almost finished. However there existed a significant absorbance peak of $\mathrm{CO}$ at $920^{\circ} \mathrm{C}$, which was due to the fact that the high temperature enhanced reduction reaction and was better for the generation of $\mathrm{CO}$.

3.2.2. Evolution Characteristics of the Main Gaseous Products with the Temperature. In order to understand the evolution characteristics of the main gaseous products during the sediment pyrolysis, the evolution curves with the temperature of the absorbance of the bands associated with $\mathrm{CO}_{2}$ $\left(2350 \mathrm{~cm}^{-1}\right), \mathrm{CH}_{4}\left(3016 \mathrm{~cm}^{-1}\right), \mathrm{CO}\left(2210 \mathrm{~cm}^{-1}\right)$, and $\mathrm{SO}_{2}$ $\left(1342 \mathrm{~cm}^{-1}\right)$ at different heating rates were presented in Figure 6. As shown in Figure 6(a), there were two evolution peaks of $\mathrm{CO}_{2}$ at three heating rates, corresponding to $385^{\circ} \mathrm{C}$ and $725^{\circ} \mathrm{C}$ at $20^{\circ} \mathrm{C} / \mathrm{min}$, corresponding to $290^{\circ} \mathrm{C}$ and $625^{\circ} \mathrm{C}$ at $10^{\circ} \mathrm{C} / \mathrm{min}$, and corresponding to $270^{\circ} \mathrm{C}$ and $618^{\circ} \mathrm{C}$ at $5^{\circ} \mathrm{C} / \mathrm{min}$, respectively. It is known that the $\mathrm{CO}_{2}$ evolution peaks shifted to the low temperature region and the peak value decreased with the decrease of heating rate. Meanwhile, the two evolution peaks were consistent to the weight loss peaks of the DTG curve at organics decomposition stage at any heating rate. Thus, the IR evolution curve of $\mathrm{CO}_{2}$ and the pyrolysis DTG curve of sediment had similar release trend and characteristic temperatures. As shown in Figure 6(b), with the temperature increasing, there was only one evolution peak of $\mathrm{CH}_{4}$ at any heating rate, corresponding to $480^{\circ} \mathrm{C}$ at $20^{\circ} \mathrm{C} / \mathrm{min}, 415^{\circ} \mathrm{C}$ at $10^{\circ} \mathrm{C} / \mathrm{min}$, and $391^{\circ} \mathrm{C}$ at $5^{\circ} \mathrm{C} / \mathrm{min}$, respectively. The generation of $\mathrm{CH}_{4}$ mainly came from methanation [24]. It is known that the $\mathrm{CH}_{4}$ evolution peak shifted to the low temperature region and the peak value increased with the decrease of heating rate. The evolution of $\mathrm{CO}$ is observed in Figure 6(c), and the IR evolution curve had been climbing gradually with the temperature increasing, which was due to the increasing reduction reaction at high temperature. The evolution difference among the three heating rates was not obvious. As shown in Figure 6(d), there was only one evolution peak of $\mathrm{SO}_{2}$ at any heating rate, corresponding 


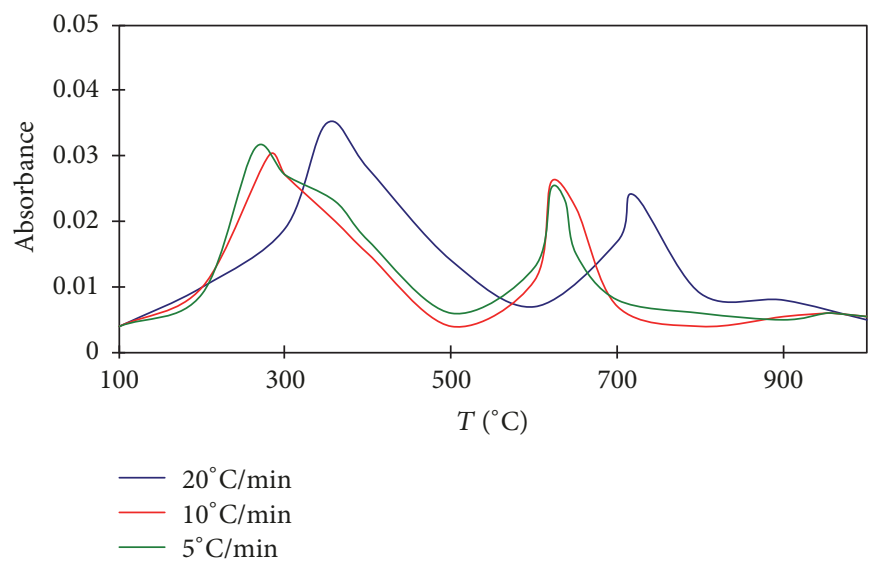

(a) $\mathrm{CO}_{2}$

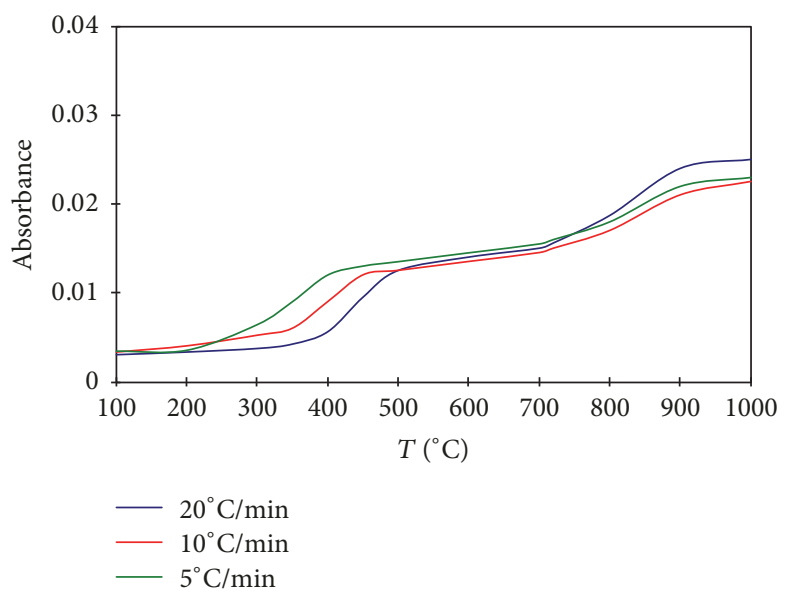

(c) $\mathrm{CO}$

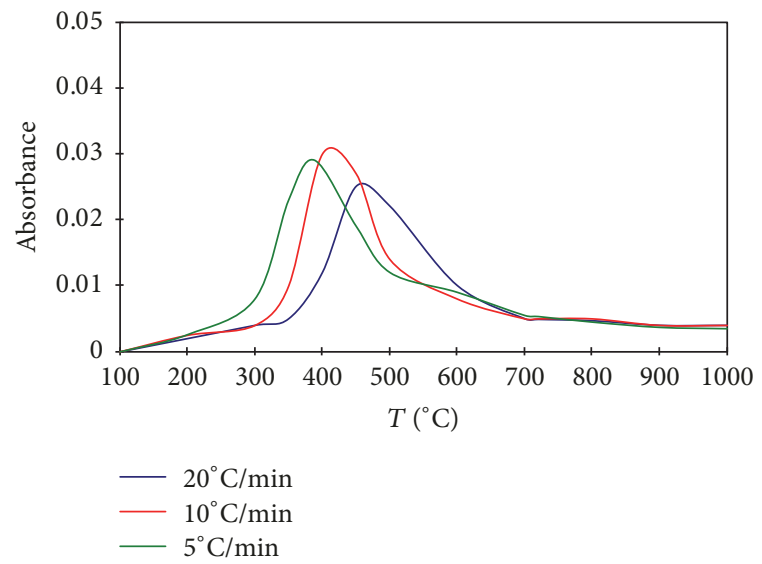

(b) $\mathrm{CH}_{4}$

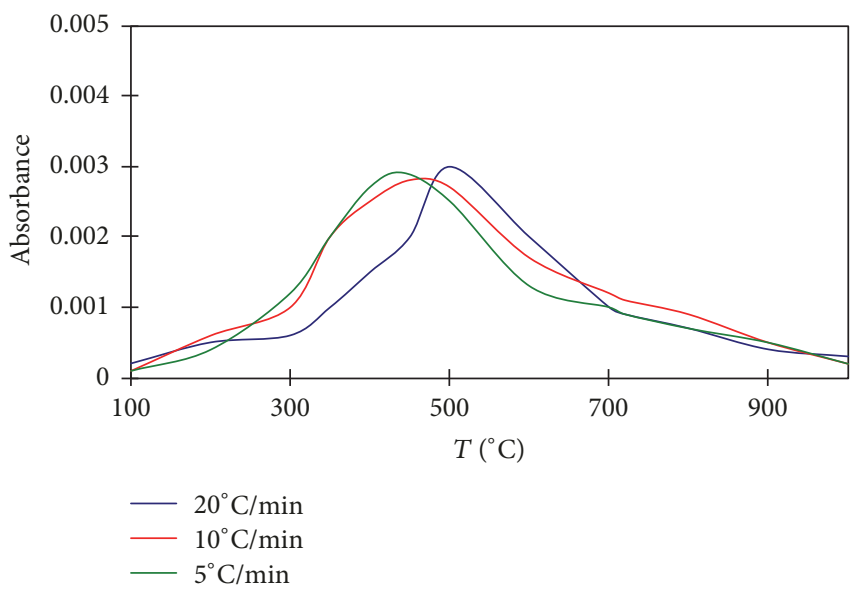

(d) $\mathrm{SO}_{2}$

Figure 6: Evolution curves of the gaseous products with temperature: (a) $\mathrm{CO}_{2}$, (b) $\mathrm{CH}_{4}$, (c), $\mathrm{CO}$ (d), and $\mathrm{SO}_{2}$.

to $500^{\circ} \mathrm{C}$ at $20^{\circ} \mathrm{C} / \mathrm{min}, 480^{\circ} \mathrm{C}$ at $10^{\circ} \mathrm{C} / \mathrm{min}$, and $472^{\circ} \mathrm{C}$ at $5^{\circ} \mathrm{C} / \mathrm{min}$, respectively. It is known that the $\mathrm{SO}_{2}$ evolution peak shifted to the low temperature region and the peak value decreased with the decrease of heating rate.

\section{Conclusions}

In the present study, the kinetic behaviors of sediment pyrolysis and evolution characteristics of the gaseous products at different heating rates were investigated by TG-FTIR. In comparison to the TG and DTG curves at different heating rates, the process of sediment pyrolysis could be considered as four stages at $10^{\circ} \mathrm{C} / \mathrm{min}$, which were the release stage of moisture and crystal water, the decomposition stage of light organic compounds, the decomposition stage of macromolecule organic matters and secondary cracking of tar and coke, and the decomposition stage of mineral salts. From the kinetics analysis, the values of $n$ at different heating rates were between 2.55 and 3.42. The $n$ th-order chemical reaction model was suitable to describe the lake sediment pyrolysis reaction well. The gaseous products of $\mathrm{H}_{2} \mathrm{O}, \mathrm{CO}_{2}$, $\mathrm{CO}, \mathrm{CH}_{4}$, and $\mathrm{SO}_{2}$ and several functional groups $(\mathrm{C}-\mathrm{H}, \mathrm{C}=\mathrm{O}$, and $\mathrm{C}-\mathrm{O}$ ) could be found from the IR spectrum. There were two evolution peaks for $\mathrm{CO}_{2}$ and one peak for $\mathrm{CH}_{4}$ and $\mathrm{SO}_{2}$.
However, the evolution of $\mathrm{CO}$ always increased. Meanwhile, the evolution peaks for $\mathrm{CO}_{2}, \mathrm{CH}_{4}$, and $\mathrm{SO}_{2}$ all shifted to the low temperature region with the decrease of heating rate.

\section{Conflicts of Interest}

The authors declare that they have no conflicts of interest.

\section{Acknowledgments}

This work was financially supported from National Nature Science Foundation of China (51766005), Key Project of Yunnan Province Nature Foundation (2015FA018), Science and Technology Project of Yunnan Tobacco Company (2015YN10), and Analysis and Testing Foundations of Kunming University of Science and Technology (2016T20060036). The authors also acknowledge the Analytical and Testing Center of Yunnan Province for providing the testing facilities.

\section{References}

[1] X. W. Wu, "The status of organic pollution in Gaoyou Lake and the study on the adsorption characteristics of sediment," Harnessing the Huaihe River, vol. 24, no. 1, pp. 44-45, 2013. 
[2] J. H. Yu, J. C. Zhong, and Y. L. Zhang, "Simulation of the influence of sediment re-suspension and nutrient loading in lake sediment," Lake Science, vol. 24, no. 1, pp. 34-42, 2012.

[3] H. Zhang and X. Y. Yang, "Thinking on the collaborative disposal of Dianchi sediment in the new dry process cement plant in Kunming," China Cement, vol. 45, no. 5, pp. 59-62, 2012.

[4] Z. F. Wu, S. P. Li, W. Li, H. L. Luo, Z. G. Gu, and S. Wang, "Feasibility analysis of gasification utilization of Eutrophic lake Dianchi dredged sediment," Journal of Kunming University of Science and Technology (Natural Science Edition), vol. 1, pp. 7276, 2016.

[5] Y. Tian, W. Zuo, Z. Ren, and D. Chen, "Estimation of a novel method to produce bio-oil from sewage sludge by microwave pyrolysis with the consideration of efficiency and safety," Bioresource Technology, vol. 102, no. 2, pp. 2053-2061, 2011.

[6] E. Smidt and V. Parravicini, "Effect of sewage sludge treatment and additional aerobic post-stabilization revealed by infrared spectroscopy and multivariate data analysis," Bioresource Technology, vol. 100, no. 5, pp. 1775-1780, 2009.

[7] A. Montusiewicz and M. Lebiocka, "Co-digestion of intermediate landfill leachate and sewage sludge as a method of leachate utilization," Bioresource Technology, vol. 102, no. 3, pp. 25632571, 2011.

[8] M. C. Samolada and A. A. Zabaniotou, "Comparative assessment of municipal sewage sludge incineration, gasification and pyrolysis for a sustainable sludge-to-energy management in Greece," Waste Management, vol. 34, no. 2, pp. 411-420, 2014.

[9] L. Zhang, X. Q. Shu, C. X. Zhan et al., "Study on Making hydrogen behaviors of coal slime and riverbed sludge via pyrolysis," Coal Engineering, vol. 4, pp. 79-82, 2008.

[10] Z. G. Gu, M. Wu, K. Li, and P. Ning, "Variation of heavy metal speciation during the pyrolysis of sediment collected from the Dianchi Lake, China," Arabian Journal of Chemistry, vol. 7, pp. 3-9, 2013.

[11] Y. X. Wang, P. Ning, and J. J. Gu, "Experimental investigation on the CO-gasification of Dianchi sediment and lignite for hydrogen production in supercritical water," Chemical Industry and Engineering Progress, vol. 32, no. 8, pp. 1960-1966, 2013.

[12] N. Gao, J. Li, B. Qi, A. Li, Y. Duan, and Z. Wang, "Thermal analysis and products distribution of dried sewage sludge pyrolysis," Journal of Analytical and Applied Pyrolysis, vol. 105, pp. 43-48, 2014.

[13] Q. Ren, C. Zhao, X. Wu et al., "TG-FTIR study on co-pyrolysis of municipal solid waste with biomass," Bioresource Technology, vol. 100, no. 17, pp. 4054-4057, 2009.

[14] X. Yang and Z. Jiang, "Kinetic studies of overlapping pyrolysis reactions in industrial waste activated sludge," Bioresource Technology, vol. 100, no. 14, pp. 3663-3668, 2009.

[15] Q. Zhang, H. Liu, P. Liu, H. Hu, and H. Yao, "Pyrolysis characteristics and kinetic analysis of different dewatered sludge," Bioresource Technology, vol. 170, pp. 325-330, 2014.

[16] P. Thipkhunthod, V. Meeyoo, P. Rangsunvigit, B. Kitiyanan, K. Siemanond, and T. Rirksomboon, "Pyrolytic characteristics of sewage sludge," Chemosphere, vol. 64, no. 6, pp. 955-962, 2006.

[17] X. Peng, X. Ma, Y. Lin et al., "Co-pyrolysis between microalgae and textile dyeing sludge by TG-FTIR: Kinetics and products," Energy Conversion and Management, vol. 100, pp. 391-402, 2015.

[18] S. Hu, A. Jess, and M. Xu, "Kinetic study of Chinese biomass slow pyrolysis: Comparison of different kinetic models," Fuel, vol. 86, no. 17-18, pp. 2778-2788, 2007.
[19] G. Liu, H. Song, and J. Wu, "Thermogravimetric study and kinetic analysis of dried industrial sludge pyrolysis," Waste Management, vol. 41, pp. 128-133, 2015.

[20] D. Vamvuka, S. Troulinos, and E. Kastanaki, "The effect of mineral matter on the physical and chemical activation of low rank coal and biomass materials," Fuel, vol. 85, no. 12-13, pp. 1763-1771, 2006.

[21] I. Mirosław and C. Andrzej, "Kinetic model of excess activated sludge thermohydrolysis," Water Research, vol. 46, no. 17, pp. 5747-5755, 2012.

[22] H. P. Yang, H. P. Chen, R. Yan, S. H. Zhang, and C. G. Zheng, "TG- FTI R analysis of palm oil wastes pyrolysis," Journal of Fuel Chemistry and Technology, vol. 3, pp. 309-314, 2006.

[23] Q. Yang, X. Yin, C. Wu, S. Wu, and D. Guo, "Thermogravimetric-Fourier transform infrared spectrometric analysis of $\mathrm{CO} 2$ gasification of reed (Phragmites australis) kraft black liquor," Bioresource Technology, vol. 107, pp. 512-516, 2012.

[24] K. Michalska, K. Miazek, L. Krzystek, and S. Ledakowicz, "Influence of pretreatment with Fenton's reagent on biogas production and methane yield from lignocellulosic biomass," Bioresource Technology, vol. 119, pp. 72-78, 2012. 


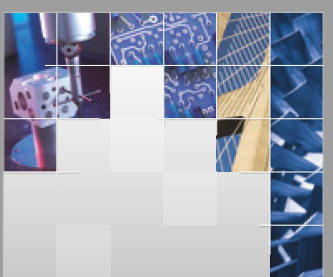

\section{Enfincering}
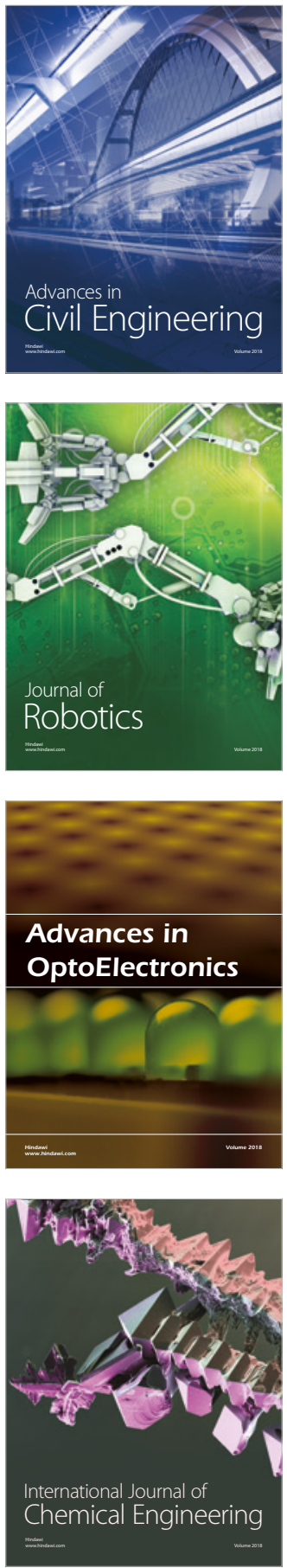

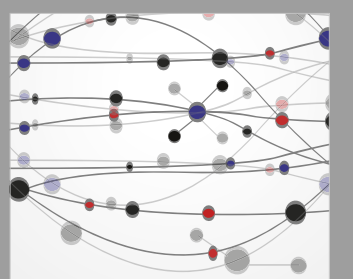

\section{Rotating \\ Machinery}

The Scientific World Journal

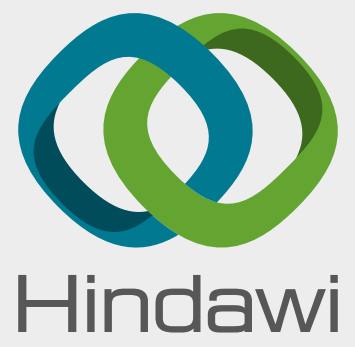

Submit your manuscripts at

www.hindawi.com
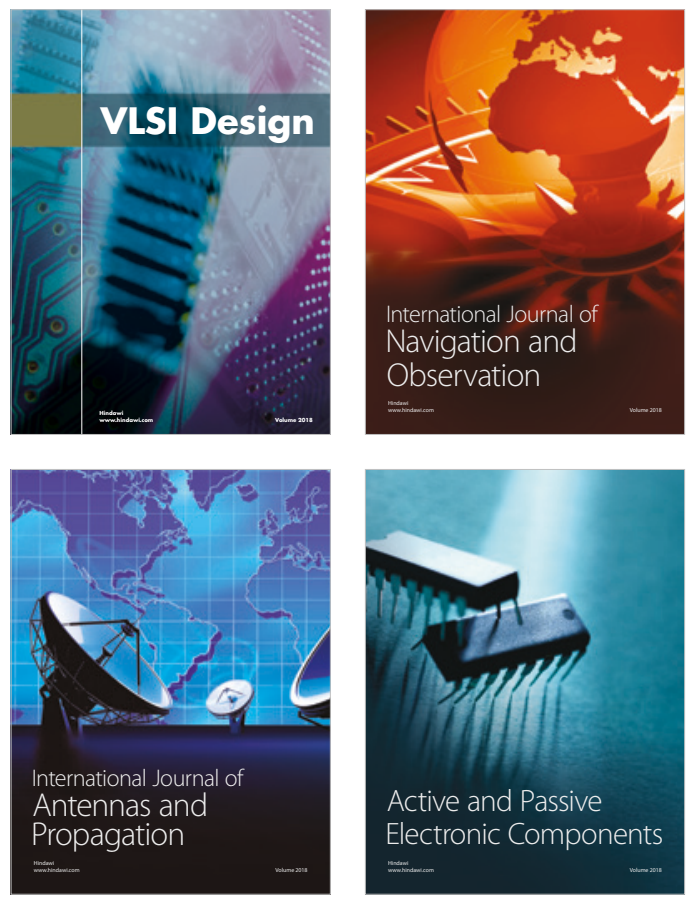
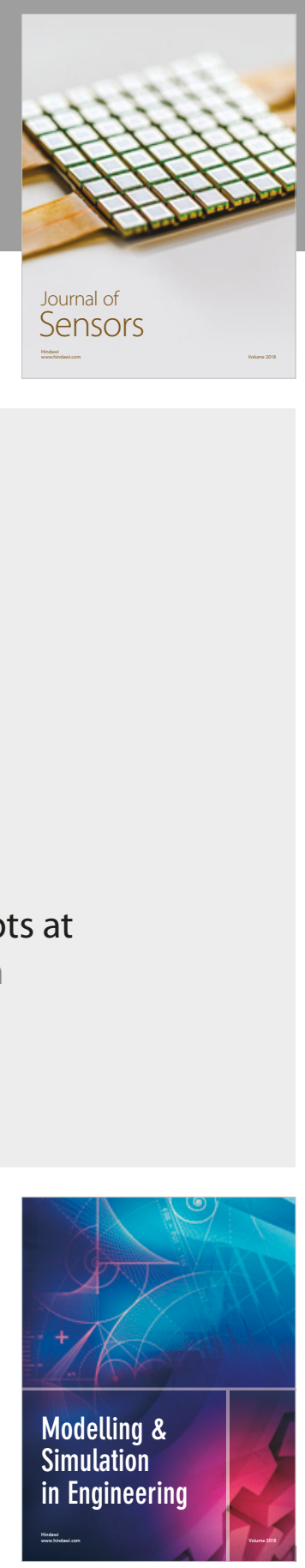

\section{Advances \\ Multimedia}
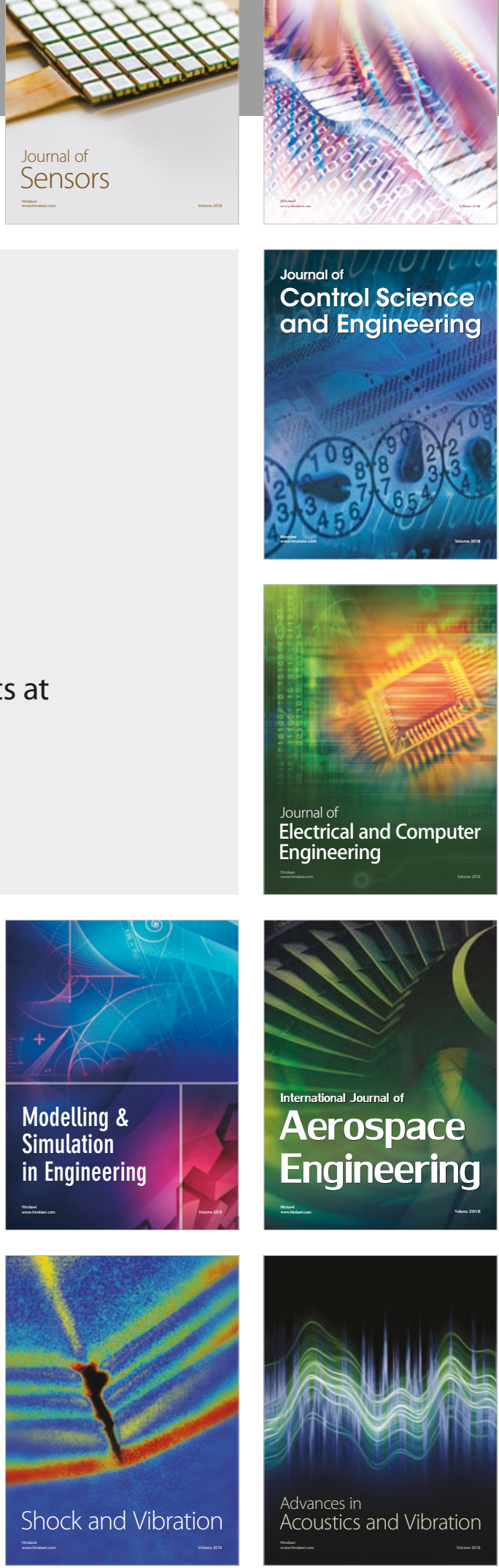